\title{
Assessment of Milk Bush Seed Oil as an Auspicious Feedstock for Biodiesel Fuel
}

\author{
Raji Ibrahim Oladayo, Ogunlusi Oluwatosin Kemisola \\ Department of Chemistry, Federal University of Technology, Akure, Nigeria \\ Email address: \\ hebrohaji@gmail.com (R. I. Oladayo)

\section{To cite this article:} \\ Raji Ibrahim Oladayo, Ogunlusi Oluwatosin Kemisola. Assessment of Milk Bush Seed Oil as an Auspicious Feedstock for Biodiesel Fuel. \\ International Journal of Computational and Theoretical Chemistry. Vol. 5, No. 5, 2017, pp. 46-52. doi: 10.11648/j.ijctc.20170505.11
}

Received: June 14, 2017; Accepted: July 10, 2017; Published: December 22, 2017

\begin{abstract}
It is indubitable that world energy demand is increasing drastically due to rapidly growing population and urbanization. It is not obscure that biodiesel would make a massively copious contribution to the energy demand at a time when the populace is becoming increasingly conscious of the declining reserves of fossil fuels and detrimental environmental effects it poses. There are several potential feedstocks that can be used for biodiesel production. The second generation feedstocks which are the non-edible vegetable oils could be considered as promising replacement for first generation feedstocks which are the edible vegetable oils. The usage of non-edible vegetable oil in the production of biodiesel is very significant because of the profuse demand for edible oils as food source. Moreover, first generation's feedstock costs are exorbitant to be used as fuel. However, in this study, non-edible milk bush (Thevettia peruviana) seed in which its seed is enrich with oil and can be grown in arid and semi-arid condition, on waste land, roadsides and road-dividers in expressways for beautification, environmental protection and hated by herbivorous animals, was used in biodiesel production. The oil was extracted with $n$-hexane using soxhlet apparatus with which ample amount $(60.2 \%)$ of oil was extracted. Biodiesel was produced via trans-esterification process from the crude oil of milk bush (Thevetia peruviana) seed with methanol. The optimum condition was obtained at molar ratio $6: 1$ of alcohol to oil, temperature of $55^{\circ} \mathrm{C}$, reaction time of 60 minutes and sodium hydroxide as the base catalyst adopted. Some fuel properties (kinematic viscosity, centane number, flash point, density, cloud point, acid value and moisture) of the biodiesel produced were determined. Results obtained for these fuel properties are $4.48 \mathrm{~mm} / \mathrm{s}, 55,135^{\circ} \mathrm{C}, 0.866,4,0.1 \mathrm{mgKOH} / \mathrm{g}, 0.03 \%$ for kinematic viscosity at $40^{\circ} \mathrm{C}$, centane number, flash point, density, cloud point, acid value and moisture content respectively. The results obtained were in agreement with ASTM D6751 and EN 14214 standards. In conclusion, it has been found that there is an immense chance to produce biodiesel from milk bush (Thevetia peruviana) seed oil and therefore it can boost the future production of biodiesel.
\end{abstract}

Keywords: Biodiesel, Milkbush, Non-edible Oil, Trans-esterification, Thevetia Peruviana

\section{Introduction}

The global increasing environmental and energy concerns caused by declining petroleum reserves and emission of green-house gases from fossil fuels have made biodiesel fuel a promising attractive energy source for the future. Biodiesel is non-petroleum based alternative source of energy. It can be defined as long chain fatty acids of mono-alkyl esters obtained from vegetable oils or animal fats and alcohol with or without a catalyst [1]. It has gained and revived the world's interest because of its sustainability, renewability, non-toxicity, availability, economic and environmental friendly advantage [2].
Vegetable oils and animal fats are the major feedstock for the production of biodiesel. The vegetable oil could be edible and non-edible but the apparent ever increasing demand of edible oils for food renders the use of non-edible oil attractive for biodiesel production [3]. Some examples of non-edible seed oil crops are; Madhuca indica (mahua), Jatropha curcas, M. azedarach (syringe), Pongamia pinnata (karanja), Hevea brasiliensis (Rubber seed), Azadirachta indica (neem), Simmondsia chinensis (Jojoba), Putranjiva roxburghii (Lucky bean tree), Sapindus mukorossi (Soapnut), Thevettia peruviana (yellow oleander/milk bush), etc. For the purpose of this study, milk bush seed oil would be adopted for the production of biodiesel. 
Milk bush (Thevettia peruviana), more commonly known as yellow oleander belongs to the family Apocyanaceae which is an evergreen ornamental dicotyledonous shrub that can be found in the tropics and sub tropics region of the world [4]. It is abundantly grown in Nigeria for ornamental purpose since it adapts so well to arid and semi-arid condition and also requires low fertility and moisture to grow [5]. The plant's seed contains about $60 \%$ oil, which hydrolyses to give about $64.3 \%$ oleic acid, $6.3 \%$ linoleic, $17.1 \%$ palmitic, $11.8 \%$ stearic, $0.4 \%$ arachidonic acid and also the cake comprise of $30-37 \%$ protein [6]. Due to the high oil value of the seed, it has a great potential to be used as a feedstock for biodiesel. Aside the high oil content of milk bush seed, it has numerous advantages which improves engine performance which are the higher heat content, lower sulphur content, lower aromatic content and the seed cakes after oil extraction can serve as fertilizers which enriches soil [7]. All parts of the plant are toxic due to the presence of cardiac glycoside which makes it non edible [8]. The non-edibility renders it more auspicious since it doesn't compete for use as food, effort should be massively intensified and explored for its maximum use in the production of biodiesel.

Conventionally, the synthesis of biodiesel from vegetable oils involves isolation of the oil from the seed and then transesterification with alcohol in the presence of an acid or base catalyst. It has been shown through various researches that the oil can be extracted using soxhlet extraction or mechanical pressing method. Moreover, the conversion of the triglyceride into an alkyl ester could be achieved through any of the following methods; blending, thermal cracking (pyrolysis), trans-esterification and micro-emulsion [9]. Trans-esterification of triglyceride with monohydric alcohol is the most commonly adopted method for the production of biodiesel from animal fats or vegetable oils with or without catalyst and has been studied for several decades and a large part has been achieved industrially using this method [10]. Therefore, the objective of this study was thus to investigate the detail process of base catalyzed trans-esterification of crude milk bush seed oil with methanol. Alongside, the influence of methanol to seed oil ratio, amount of alkali $(\mathrm{KOH})$ catalyst, temperature and reaction time was examined to identify the optimal reaction conditions and define best performance of biodiesel yield and quality. The fuel properties of milk bush seed oil methyl-esters (biodiesel) in comparison with the accepted biodiesel standards were also investigated.

\section{Materials and Method}

\subsection{Materials}

Fresh matured fruits of milk bush (T. peruviana) were obtained from Ehirobo street, Bells University drive, Sango Ota, Ogun State, Nigeria on the $4^{\text {th }}$ of March, 2016. The fruits were immediately transported to the laboratory where they were manually separated to remove all forms of impurities. The clean seeds were dried at room temperature for several days after which they were milled with blender. Methanol ( $>98 \%$ purity), n-hexane ( $>98 \%$ purity) and all solvents and chemicals used were pure and of analytical grades.

\subsection{Oil Extraction}

A known weight of the dried milled milk bush seed was subjected to soxhlet extraction using two hundred millilitres (200 ml) of $\mathrm{n}$-hexane which was placed in a $500 \mathrm{ml}$ round bottom flask of the soxhlet apparatus. The Soxhlet apparatus was mounted to a heating mantle and was heated between $60^{\circ} \mathrm{C}-65^{\circ} \mathrm{C}$ so as to prevent loss of hexane vapour because nhexane has a boiling point of $69^{\circ} \mathrm{C}$. The evaporating $n$-hexane was condensed into the thimble by the condenser where it leached the oil out of the paste. The oil rich solvent after reaching a level siphoned back automatically into the round button flask where the process described so far was repeated. The solvent was recovered using rotary evaporator which leaves behind solvent free milk bush seed oil and it was weighed to calculate the percentage yield [11].

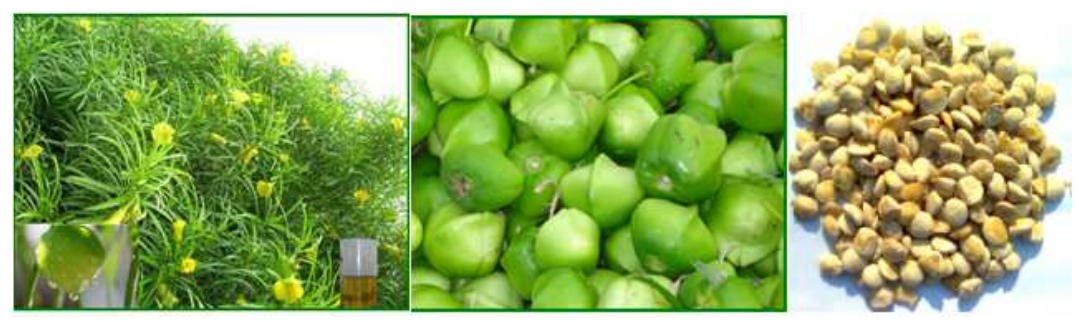

Figure 1. Milk bush plant with its fruit and seed.

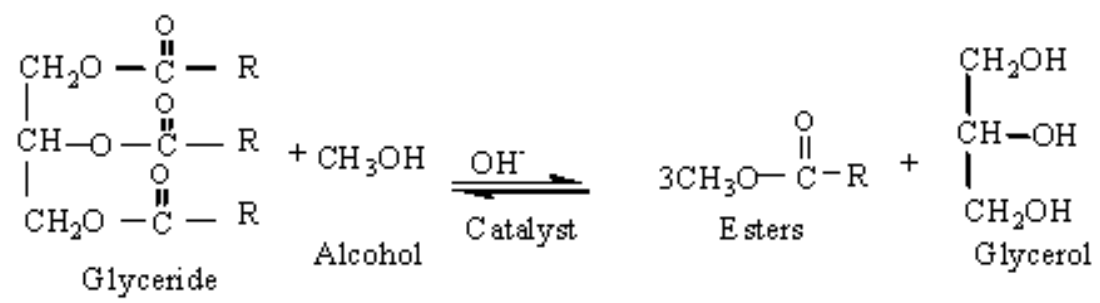




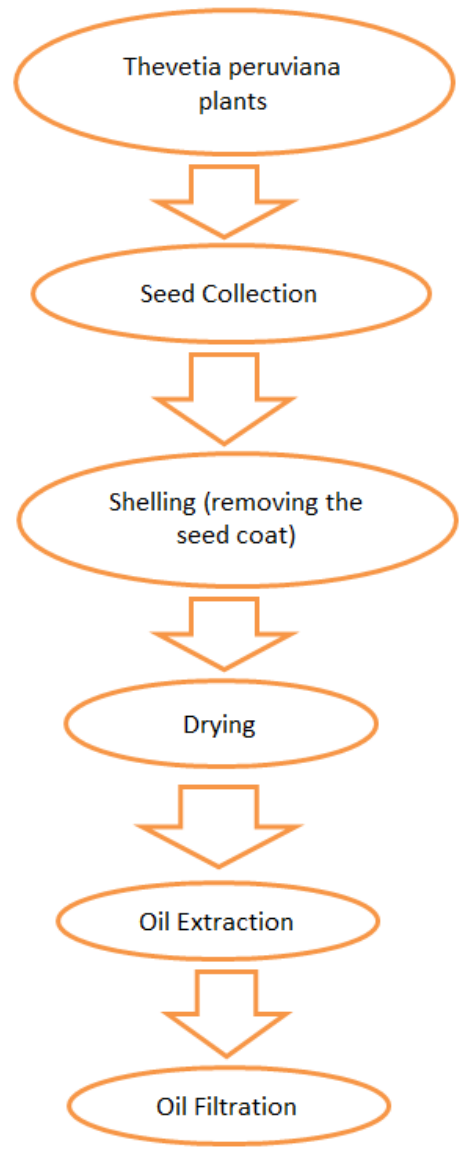

Figure 3. Sample preparation flowchart of Thevetia peruviana seed oil [11].

\subsection{Analysis of Thevettia Peruviana Oil}

Some physico-chemical properties with which vegetable oils are identified as recommended by American Standard Testing Method (ASTM), Association of Official Analytical Chemists (AOAC) and other standards were determined for the extracted milk bush (Thevetia peruviana) seed oil. These are specific gravity, refractive index, percentage free fatty acid (FFA), saponification value, viscosity, peroxide value and moisture content.

\subsection{Preparation of Catalysts}

The amount and type of catalyst adopted is one of the important factors that determine the yield of biodiesel. The essence of the titration process is to get the number of gram of $\mathrm{NaOH} / \mathrm{KOH}$ that would be used in the trans-esterification process. A lye was prepared using sodium hydroxide $(\mathrm{NaOH})$ in which 1 gram of $\mathrm{NaOH}$ was dissolved in 1 Litre (L) of distilled water to make $0.1 \%$ lye. $10 \mathrm{~mL}$ of isopropyl alcohol was used to dissolve $1 \mathrm{~g}$ of crude milk bush seed oil which was warmed gently in a water bath until it completely dissolved. Thereafter, 2 drops of phenolphthalene solution was added to the mixture in which $0.1 \% \mathrm{NaOH}$ was titrated against the mixture until a stable pink colour was formed. The average titre value of $\mathrm{NaOH}$ in addition to $4 \mathrm{~g}$ of $\mathrm{NaOH}$ (catalyst) will be needed for transesterification of the milk bush seed oil extracted [12].

\subsection{Production of Biodiesel (Transesterification of Milk Bush Seed Oil)}

The crude milk bush seed oil was trans-esterified in batches to calculate the yield of biodiesel. $250 \mathrm{~mL}$ of milk bush seed oil was measured into a three necked flask fitted to a thermometer and liebig condenser and was heated to $50^{\circ} \mathrm{C}$ in a closed system. Thereafter, $3.75 \mathrm{~g}$ of $\mathrm{NaOH}$ was dissolved in $50 \mathrm{~mL}$ of methanol in a covered bottle and shakened thoroughly to dissolve the salt. The methanol and sodium hydroxide mixture (methoxide) was poured into the heated oil and simultaneously heated and stirred using a magnetic stirrer bar at a temperature of $55^{\circ} \mathrm{C}$.

The mixture was allowed to cool, transferred to the separating funnel and allowed to stand for 24 hours for good separation. After 24 hours, two distinct layers were observed, in which the upper layer is the fatty acid methyl ester (biodiesel) and the lower layer is the glycerol because glycerol is heavier than the biodiesel formed. The biodiesel was washed with warm distilled water for four to five times until a clear solution was observed in the lower layer, after the completion of washing process the biodiesel may contain some traces of water. Biodiesel was placed on a water bath heated to $105^{\circ} \mathrm{C}$ to remove the trapped traces of water (for drying) [12].

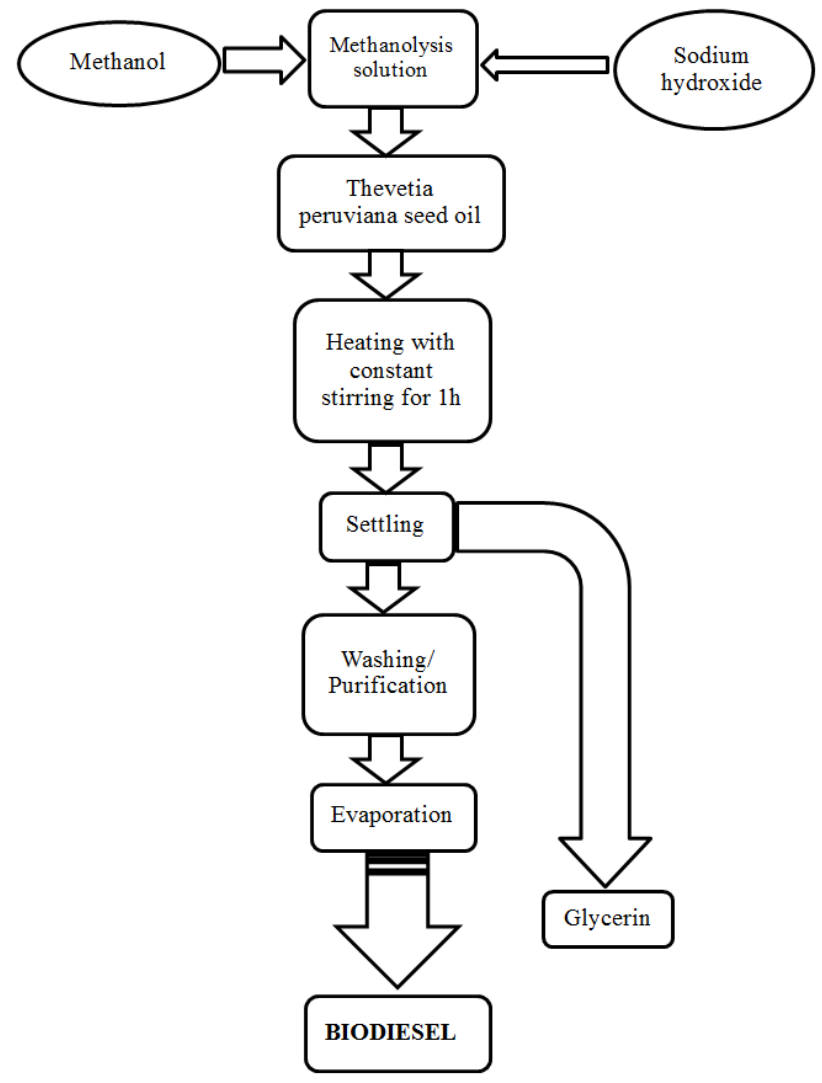

Figure 4. Trans-esterification flow process for biodiesel production [13].

\section{Results and Discussion}

After extraction, oil extracted from milkbush seed was 
golden yellow in colour and free of sediments. The percentage of oil from the seed of Thevetia peruviana was determined. The homogeneous base catalysed trans-esterification of the extracted oil and physico-chemical properties of oil and biodiesel were carried out. In addition, the optimum conditions such as oil/methanol molar ratio, reaction temperature and time, effect of catalyst were investigated to determine highest yield of the biodiesel quantitatively.

\subsection{Percentage Oil Yield from Milk Bush Seed}

Golden yellow oil was obtained from the milk bush seed after extraction. The percentage of oil extracted is shown in Table 1.

Table 1. Percentage of Oil Extracted.

\begin{tabular}{lll}
\hline $\mathbf{W}_{\mathbf{1}}(\mathbf{g})$ & $\mathbf{W}_{\mathbf{2}}(\mathbf{g})$ & \% Oil yield \\
\hline 1000 & 398 & 60.2 \\
\hline
\end{tabular}

$\mathrm{W}_{1}$ is the weight of the sample before extraction. $\mathrm{W}_{2}$ is the weight of the sample after extraction.
This value showed high oil yields. Milk bush seed oil has been worked on extensively and the percentage oil yields have been found to be promising and comparable with the values obtained in other studies. Ibiyemi, 2002 [14] found appreciable percentage oil yields of $64 \%$ for Y. Oleander. Olisakwe et al. 2011 [15] also reported a little higher yield for Jatropha and Yellow oleander (54.6\% and 58.5\% respectively).

Table 2. Physico-chemical parameters of the extracted oil.

\begin{tabular}{lll}
\hline S/N & PARAMETERS & VALUES \\
\hline 1 & Refractive index & 1.4660 \\
2 & Specific gravity & 0.912 \\
3 & Acid value & 4.2 \\
4 & Free Fatty Acid & 2.1 \\
5 & Saponification value & 60.68 \\
6 & Peroxide value & 3.9 \\
7 & Moisture content $(\%)$ & 0.58 \\
8 & Viscosity at $40^{\circ} \mathrm{C}(\mathrm{Pa} / \mathrm{s})$ & 7.8 \\
\hline
\end{tabular}

Table 3. Comparison of the fuel properties of the biodiesel produced from milk bush seed oil with American Society of Testing and Materials (ASTM) biodiesel standard [16].

\begin{tabular}{llll}
\hline Property & Present Study & $\begin{array}{l}\text { ASTM D6751 Biodiesel } \\
\text { standard }\end{array}$ & Test method \\
\hline Flash point $\left({ }^{\circ} \mathrm{C}\right)$ & 135 & $130.0 \mathrm{~min}$ & $\begin{array}{l}\text { EN 14214 Biodiesel } \\
\text { Standard }\end{array}$ \\
Moisture content $(\%)$ & 0.03 & $0.050 \mathrm{max}$ & ASTM D93 \\
Density & 0.866 & $0.86-0.900$ & ASTM D2709 \\
Kinematic Viscosity at $40{ }^{\circ} \mathrm{C}\left(\mathrm{mm}^{2} / \mathrm{s}\right)$ & 4.48 & $1.9-6.0$ & ASTM D1928 \\
Centane Number & 55 & 47 min & ASTM D445 \\
Cloud point $\left({ }^{\circ} \mathrm{C}\right)$ & 4 & 3 to 12 & ASTM D613 \\
Acid value $(\mathrm{mgKOH} / \mathrm{g})$ & 0.1 & 0.5 max & ASTM 2500 \\
\hline
\end{tabular}

Table 4. Fuel properties of T. peruviana methyl ester (TPME) reported in various literatures and their comparison with the present study.

\begin{tabular}{|c|c|c|c|c|}
\hline Properties & Present study & Adebowale et al. [17] & Deka et al. [18] & Betiku et al. [19] \\
\hline Flash point $\left({ }^{\circ} \mathrm{C}\right)$ & 135 & 125 & 75 & 196 \\
\hline Cloud point $\left({ }^{\circ} \mathrm{C}\right)$ & 12 & ----- & 12 & 8 \\
\hline Density & 0.866 & 0.870 & 0.875 & 0.887 \\
\hline Kinematic Viscosity at $40^{\circ} \mathrm{C}\left(\mathrm{mm}^{2} / \mathrm{s}\right)$ & 4.48 & 4.50 & 4.33 & 6.0 \\
\hline Centane Number & 55.2 & 54.2 & 61.5 & 123.5 \\
\hline Acid Value (mg KOH/g) & 0.100 & 0.20 & 0.057 & 0.46 \\
\hline Moisture content $(\%)$ & 0.03 & ----- & ----- & ----- \\
\hline
\end{tabular}

\subsection{Fuel Properties of Biodiesel Produced from Thevetia Peruviana Seed Oil}

The properties such as the kinematic viscosity at $40^{\circ} \mathrm{C}$, density at $25^{\circ} \mathrm{C}$, flash point, cloud point, acid value, moisture content, centane number were investigated and reported.

\subsubsection{Kinematic Viscosity}

The kinematic viscosity at $40^{\circ} \mathrm{C}$ of TPME was determined to be $4.48 \mathrm{~mm}^{2} / \mathrm{s}$ which is within the biodiesel standard set by ASTM D6751 and EN 14214 with prescribe viscosity ranges of $1.9-6.0$ and $3.5-5.0 \mathrm{~mm}^{2} / \mathrm{s}$, respectively. The value $\left(4.48 \mathrm{~mm}^{2} / \mathrm{s}\right)$ agrees well with $4.50 \mathrm{~mm}^{2} / \mathrm{s}$ and $4.33 \mathrm{~mm}^{2} / \mathrm{s}$ reported by Adebowale et al. [17] and Deka et al. [18] respectively, who produced methyl esters (biodiesel) from the oil of Thevetia peruviana. Also, Betiku et al. [19] produced biodiesel from yellow oleander oil with kinematic viscosity value of $6.0 \mathrm{~mm}^{2} / \mathrm{s}$ which is slightly higher than the present study $\left(4.48 \mathrm{~mm}^{2} / \mathrm{s}\right)$ and falls above $3.5-5.0 \mathrm{~mm}^{2} / \mathrm{s}$ biodiesel standard set by ASTM D6751 but falls within that of EN 14214.

\subsubsection{Cetane Number}

For the determination of diesel fuel quality, especially the ignition quality, the cetane number is an important parameter which measures the readiness of the fuel to autoignite when it is injected into the engine [20]. As shown in Table 3, the cetane number of TPME was determined to be 55.2 which is in agreement with 54.2 reported by Adebowale et al. [17] and considerably lower compared to 61.5 reported by Deka et al. [18]. High centane number 123.5 reported by Betiku et al. [19] implies short ignition delay and fuels with low centane number tend to cause 
incomplete combustion as a result of increased gaseous and particulate exhaust emissions [21]. The centane number of Thevetia peruviana derived biodiesel investigated in this study agrees with the minimum cetane number requirements in both the ASTM D6751 and EN 14214 biodiesel standards, which are 47 and 51, respectively.

\subsubsection{Flash Point}

Flash point is another important property of biodiesel fuel, which is the lowest temperature at which it will spontaneously ignite when exposed to a flame or spark. Biodiesels have quite high flash points which make them less volatile and safer to transport or handle compare to diesel fuel. As shown in Table 3, the flash point of TPME fuel is $135^{\circ} \mathrm{C}$ which can be compared well with ASTM D6751 and EN 14214 biodiesel specifications with the minimum of $130^{\circ} \mathrm{C}$ and $120^{\circ} \mathrm{C}$ respectively. It can also be compared with that reported by Adebowale et al. [17] who produced methyl esters (biodiesel) from the oil of Thevetia peruviana and the flash point was found to be $125^{\circ} \mathrm{C}$ which is slightly below $130^{\circ} \mathrm{C}$ set by ASTM D6751 and slightly above $120^{\circ} \mathrm{C}$ set by EN 14214 biodiesel specifications. Deka et al. [18] also produced biodiesel from the oil of Thevetia peruviana with flash point $75^{\circ} \mathrm{C}$ that is drastically below the biodiesel specifications.

\subsubsection{Density}

Density is the relationship between the mass and volume of any liquid or a solid at a given temperature expressed in units of grams per liter $(\mathrm{g} / \mathrm{L})$. The density of diesel oil gives an indication of the delay between the injection and combustion of the fuel in a diesel engine and the energy per unit mass [22]. The test method ASTM D1298 was adopted to measure the density of the biodiesel. From Table 3, it has been found that TPME has density of $0.867 \mathrm{~g} / \mathrm{cm}^{3}$ which is in conformity with the standard $0.86-0.9 \mathrm{~g} / \mathrm{cm}^{3}$ set by ASTM D6751. According to these standards, density should be tested at the temperature reference of $15^{\circ} \mathrm{C}$ [23]. Hotti and Hebbal, 2015 [24] reported that the density of biodiesel obtained from non-edible seed oil is higher than that of conventional diesel fuel and may be attributed to the presence of higher molecular weight triglycerides.

\subsubsection{Acid Value}

Acid value measures the amount of carboxylic acid groups in a chemical compound, such as a fatty acid, or in a mixture of compounds. Acid value is a relevant parameter which provides indication of the level of lubricant degradation while the fuel is in service [25]. It is usually expressed as $\mathrm{mg}$ $\mathrm{KOH} / \mathrm{g}$ and is set to a maximum value of $0.5 \mathrm{mg} \mathrm{KOH} / \mathrm{g}$ in the European standard (EN 14104) and ASTM D664. From Table 3, the acid value of TPME was determined to be 0.1 $\mathrm{mg} \mathrm{KOH} / \mathrm{g}$ which falls within the set standard and it is in agreement with the acid values $0.057 \mathrm{mg} \mathrm{KOH} / \mathrm{g}, 0.20 \mathrm{mg}$ $\mathrm{KOH} / \mathrm{g}$ and $0.46 \mathrm{mg} \mathrm{KOH} / \mathrm{g}$ reported by deka et al. [18] adebowale et al. [17] and betiku et al. [19] respectively. The presence of higher acid content can cause severe corrosion in internal combustion engine and fuel supply system [25].

\subsubsection{Moisture Content}

Moisture is a common component that is usually found in all feed-stocks. Moisture reacts with the catalyst during transesterification reaction which leads to soap formation [26]. Biodiesel is generally considered to be insoluble in water and it actually takes up considerably more amount of water than diesel fuel [26]. Hence, before biodiesel production or during ester purification moisture must be eliminated [27]. The moisture content $0.030 \mathrm{wt} \%$ in the biodiesel was determined in accordance to EN1412 with specification of $0.050 \mathrm{wt} \%$ maximum. However, the moisture content of biodiesel is encouraged to be profusely eliminated to avoid reduction in the heat of combustion which could further cause corrosion of fuel system components [28].

\subsection{Effect of Different Reaction Parameters on the Biodiesel Yield}

There are several factors that enhance the yield of alkyl ester during transesterification reaction. These variables include alcohol/oil molar ratio, reaction time, reaction temperature, water content, and FFA content [29].

\subsubsection{Effect of Molar Ratio of Alcohol to Oil and Alcohol Type}

Molar ratio of alcohol to oil is one of the most important factors that affect the yield of alkyl ester. Generally, short chain alcohols such as methanol, ethanol, propanol, and butanol can be used in the trans-esterification reaction while it is encouraged to use the alcohol of shorter chain to obtain high alkyl ester yields [30]. Stoichiometrically, one mol (1 mol) of triglyceride and three mols $(3 \mathrm{~mol})$ of alcohol are required in trans-esterification reaction to yield three mols $(3 \mathrm{~mol})$ of fatty acid ester and one mol (1 mol) of glycerol [31]. Higher alcohol/oil molar ratios are required to influence the solubility between the triglyceride and alcohol molecules. The alcohol/oil molar ratio of $6: 1$ or higher generally gives the maximum yield (higher than $98 \mathrm{wt} \%$ ) [32]. However, the higher molar ratio is required to complete the reaction at higher rate. The yield of methyl ester could be increased by introducing an excess amount of methanol to shift the equilibrium to the right [33]. There was a significant effect on the yield of biodiesel for the variation of methanol to oil molar ratio. The yield of TPME increases as additional methanol was added.

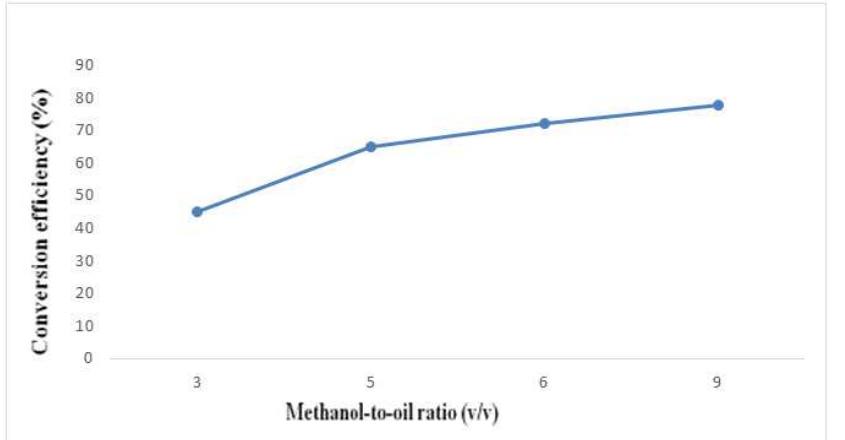

Figure 5. The effect of methanol-to-oil variation on the conversion efficiency. 


\subsubsection{Effect of Reaction Temperature and Time}

The reaction temperature plays an important role in alkaline-catalyst trans-esterification. At room temperature there was no significant yield and it was observed that increase in the reaction temperature had a massive influence on the yield of ester conversion. The effect of temperature variation on conversion efficiency is shown in figure 6 . The temperature was varied at four different levels such as 45,50 , 55 and $60^{\circ} \mathrm{C}$ with which $55^{\circ} \mathrm{C}$ gave maximum methyl ester yield. There is a greater chance of losing the methanol if the temperature is greater than $60^{\circ} \mathrm{C}$, because the melting point of methanol is $63.4^{\circ} \mathrm{C}$. Also, with higher temperature, there is possibility of having higher glycerol yields and lower biodiesel yields [34].

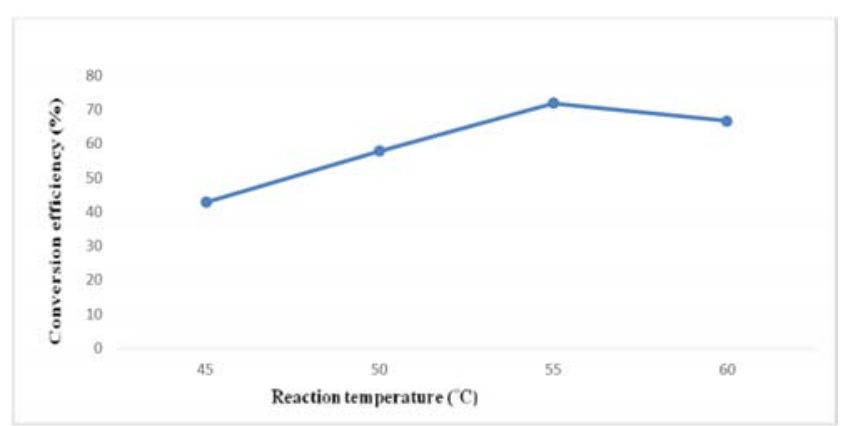

Figure 6. The effect of reaction temperature variation on the conversion efficiency.

Moreover, the methyl ester conversion rate was observed to increase with increase in reaction time. The effect of reaction time variation on the conversion efficiency is shown in figure 7 . The maximum efficiency achieved was $72.13 \%$ with reaction time of 1 hour.

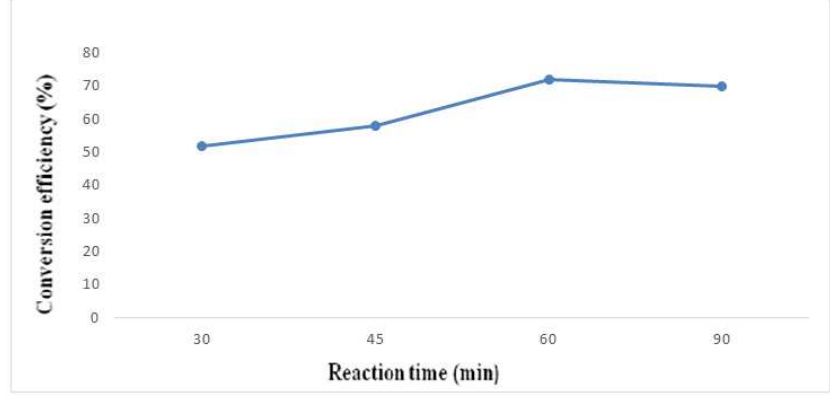

Figure 7. Effect of reaction time variation on the conversion efficiency.

Different reaction time for the transesterification process have been reported by different researchers. Kim et al. (2004) [35] studied the transesterification reaction, with maximum biodiesel yield within 1 hour.

\section{Conclusion}

Recently, biodiesel which is a mixture of methyl esters of long chain fatty acids has become increasingly attractive because of its apparent economic and environmental benefits. The fuel properties of biodiesel produced from milk bush seed oil determined in this study were found to be comparable to those of ASTM D6751 and EN 14214 biodiesel standards. Therefore, from this research, it can be concluded that Thevetia peruviana seed oil can be a potential alternative to produce biodiesel which could create biodiversification from over dependency on limited fossil fuel, reduce the threat of global warming and help solve socioeconomic problem. Production of biodiesel from low cost non-conventional and non-edible oil resources is most preferred compared to biodiesel from edible oil resource because it can be grown on waste land areas and does not compete with food crops which bring about the issue of food versus fuel.

\section{References}

[1] Agarwal A. K, Rajamanoharan K, 2007. Biofuels (alcohols and biodiesel) applications as fuels for internal combustion engines. Progress in Energy and Combustion Science, 33 (3): 233-71.

[2] Yap A, 2004. Quinn N. editors. Biodiesel - fuel for the future. Environmental Technology pp. 2-8.

[3] Van Gerpen J, Shanks B, Pruszko R, Clements D, Knothe G, 2004. Biodiesel production technology. NREL/SR-510-36244.

[4] Fernando S, Karra P, Hernandez R, Jha S. K, 2007. Effect of incompletely converted soybean oil on biodiesel quality. Energy; 32 (5): 844-51.

[5] Azam M. M, Waris A, Nahar N. M, 2005. Prospects and potential of fatty acid methyl esters of some non-traditional seed oils for use as biodiesel in India. Biomass and Bioenergy; 29 (4): 293-302.

[6] Jairo, C. A 1981. Phytochemical study of the fixed oil of Theretia peruviana seeds. Chemical Abstracts, 95: $3414 \mathrm{~m}$.

[7] Ahmad A. L, Yasin N. H. M, Derek C. J. C, Lim J. K, 2011. Microalgae as a sustainable energy source for biodiesel production: a review. Renewable and Sustainable Energy Reviews, 15 (1): 584-93.

[8] Oluwaniyi O. O, Ibiyemi S. A, Usman L. A, 2007. Effect of detoxification on the nutrient content of Thevetia peruviana seed cake, Research Journal of Applied Sciences., 2 (2): 188 191.

[9] Otera, J., 2003. Esterification-Methods, Reactions and Applications. John Wiley and Sons, VCH-Gmb Hand Co.

[10] Leung D. Y. C, Wu X, Leung M. K. H, 2010. A review on biodiesel production using catalyzed transesterification. Applied Energy; 87: 1083-95.

[11] Singh S. P, Singh D, 2010. Biodiesel production through the use of different sources and characterization of oils and their esters as the substitute of diesel: a review. Renewable and Sustainable Energy Reviews; 14 (1): 200-16.

[12] Sekhar M. C, Mamilla V. R, Mallikarjun M. V, Reddy K. V. K, 2009. Production of biodiesel from neem oil. International Journal of Engineering Studies; 1 (4): 295-302.

[13] Meher L. C, Sagar V. D, Naik S. N, 2006. Technical aspects of biodiesel production by transesterification, Renewable and Sustainable Energy Reviews; 10 (3): 248-68. 
[14] Ibiyemi SA, Fadipe VO, Akinremi OO, Bako SS, 2002. Variation in oil composition of Thevetia peruviana Juss (Yellow Oleander) fruits seeds, Journal of Applied Science and Environmental Management. (JASEM), 6 (2): 61 - 65.

[15] Olisakwe H. C, Tuleun L. T, Eloka-Eboka, 2011. Comparative study of Thevetia peruviana and Jatropha curcas seed oils as feedstock for grease production, International Journal of Engineering Research and Applications (IJERA). 1: 793-806.

[16] Murugesan A, Umarani C, Chinnusamy T. R, Krishnan M, Subramanian R, Neduzchezhain N, 2009. Production and analysis of biodiesel from non-edible oils-a review. Renewable and Sustainable Energy Reviews; 13 (4): 825-34.

[17] Adebowale, K. O., Adewuyi, A., Ajulo, K. D., 2012. Examination of fuel properties of the methyl esters of Thevetia peruviana seed oil, International Journal of Green Energy; 9, 297-307.

[18] Deka, D. C., Basumatary, S., 2011. High quality biodiesel from yellow oleander (Thevetia peruviana) seed oil, Biomass Bioenergy, 35, 1797-1803.

[19] Betiku, E., Ajala, S. O., 2014. Modeling and optimization of Thevetia peruviana (yellow oleander) oil biodiesel synthesis via Musa paradisiacal (plantain) peels as heterogeneous base catalyst: A case of artificial neural network vs. response surface methodology, Industrial Crops Production, 53, 314 322 .

[20] Bamgboye A. I and Hansen A. C, 2008. Prediction of cetane number of biodiesel fuel from the fatty acid methyl ester (FAME) composition. International Agrophysics. 22 (1): 21.

[21] Basha S. A, Gopal K. R, Jebaraj S., 2009. A review on biodiesel production, combustion, emissions and performance. Renewable and Sustainable Energy Reviews; 13 (6-7): 1628 34.

[22] Anwar F, Rashid U, Ashraf M, Nadeem M. Okra, 2010. Hibiscus esculentus seed oil for biodiesel production. Applied Energy; 87 (3): 779-85.

[23] Chung K. H, 2010. Transesterification of Camellia japonica and Vernicia fordii seed oils on alkali catalysts for biodiesel production. Journal of Industrial and Engineering Chemistry 16 (4): 506-9.
[24] Hotti S. R and Hebbal O. D, 2015. Biodiesel production and fuel properties from non-edible champaca (michelia champaca) seed oil for use in diesel engine. Journal of Thermal Engineering 1 (1): 330336.

[25] Ramos M. J, Fernandez C. M, Casas A, Rodriguez L, Pe'rez A, 2009. Influence of fatty acid composition of raw materials on biodiesel properties. Bioresource Technology 100 (1): 2618. s

[26] Aliyu B, Agnew B, Douglas S, 2010. Croton megalocarpus (Musine) seeds as a potential source of biodiesel. Biomass and Bioenergy 34 (10): 1495-9.

[27] Karmakar A, Karmakar S, Mukherjee S, 2010. Properties of various plants and animals feedstocks for biodiesel production. Bioresource Technology; 101 (19): 7201-10.

[28] Demirbas A, 2009. Progress and recent trends in biodiesel fuels. Energy Conversion and Management; 50 (1): 14-34.

[29] Madras G, Kolluru C and Kumar R, 2004. Synthesis of biodiesel in supercritical fluids. Fuel 83 (14): 2029-2033.

[30] Antolin G. F, 2002. Optimization of Biodiesel production by sunflower oil transesterification. Bioresource Technology, 83 (2): 111-114.

[31] Agarwal, A. K. and Das L. M, 2001. Biodiesel Development and characterization for use as a fuel in compression Ignition Engine. Journal of Engineering. ASME, 123 (2): 440-447.

[32] Noureddini H, Harkey D and Medikonduru V, 1998. A Continuous process for the conversion of vegetable oils into methyl esters of fatty acids. Journal of the American Oil Chemists' Society 75 (12): 1775-1783.

[33] Anitha, Dawn S. S, 2010. Performance Characteristics of Biodiesel Produced from Waste Groundnut Oil using Supported Heteropolyacids. International Journal of Chemical Engineering and Applications, 1 (3), 261-265.

[34] Leung D. Y. C and Guo Y, 2006. Transesterification of neat and used frying oil: Optimization for biodiesel production. Fuel Processing Technology 87 (10): 883-890

[35] Kim H. J, Kang B. S, Kim M. J, 2004. Transesterification of vegetable oil to biodiesel using heterogeneous base catalyst. Catalysis Today 93: 315-320. 